ZABOKRYTSKYY I. I.,

Candidate of Juridical Sciences (PhD), Associate Professor of the Department of Constitutional and International law (Institute of Law, Psychology and Innovative Education of Lviv Polytechnic National University)

UDC 340

DOI https://doi.org/10.32842/2078-3736-2019-6-1-4

\title{
TRENDS OF HUMAN RIGHTS PROTECTION IN THE EUROPEAN UNION AS A FEATURE OF MODERN CONSTITUTIONALISM TRANSNATIONALIZATION
}

The article examines modern trends of human rights protection in the European Union as a feature of modern constitutionalism transnationalization. The role of the European Union Agency for Fundamental Rights is described as well as of annual reports of the European Commission on the application of the EU Charter of the Fundamental Rights. The article also analyzes the ways that national authorities interpret the EU Charter of the Fundamental Rights during application and enforcement of law. The role of General Data Protection Regulation (GDPR) is examined in the context of extraterritoriality of its application. The conclusion is made that the protection of human rights within the European Union has a transnational effect and is also evidence of the transnationalization of modern constitutionalism. It is stated that within the EU, we see a close interconnection and interaction between national law of the Member States, the European Union law and the European Convention for the Protection of Human Rights and Fundamental Freedoms, in order to provide the greatest possible protection for the human rights. There has also been an increase in attention to these issues in the last decade, in particular, because of the entry into force of Charter of Fundamental Rights of the EU and the founding of the EU Agency for Human Rights. The application of the Charter also faces certain challenges, in particular, national courts and parliaments could apply it more frequently, conflicts may arise between national constitutional law and European Union law, at the same time national constitutional justice bodies try to build their activities more amicable to the EU law and engage in an active dialogue through appeals to the European Union Court of Justice with the aim to interpret both the Charter and its case-law, an sometimes its amendments. Finally, another trend of transnationalization is the extraterritorial effect that we can see on the GDPR example - in the modern world, where digital technologies, the Internet, the increasing role of personal data are receiving increasing attention, which necessitated extending the effect of GDPR including controllers or processors based outside the EU.

Key words: EU Charter of Fundamental Rights, human rights protection in the EU, trends of human rights protection in the EU, SOLVIT, EU Agency for Fundamental Rights, GDPR.

У статті досліджено сучасні тенденції захисту прав людини в Свропейському Союзі як ознаку транснаціоналізації сучасного конституціоналізму. Описано роль Агентства Європейського Союзу з основоположних прав, а також

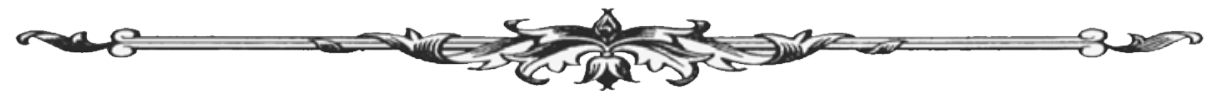


щорічних звітів Європейської Комісії про застосування Хартії основоположних прав СС. У статті також проаналізовано способи, якими національні органи тлумачать Хартію основоположних прав СС під час застосування та виконання законодавства. Роль Загального регламенту щодо захисту даних (GDPR) розглядається в контексті екстериторіальності його застосування. Зроблено висновок, що захист прав людини в межах Свропейського Союзу має транснаціональну дію, а також є свідченням транснаціоналізації сучасного конституціоналізму. Зазначається, що в межах ЄС ми бачимо тісний взаємозв'язок та взаємодію між національним законодавством держав-членів, законодавством Свропейського Союзу та Європейською конвенцією про захист прав людини та основоположних свобод, щоб забезпечити максимально можливий захист права людини. За останні десятиліття також спостерігається посилення уваги до цих питань, зокрема, через набуття чинності Хартією основоположних прав СС та створення Агентства ЄС 3 прав людини. Застосування Хартії також стикається 3 певними викликами, зокрема, національні суди та парламенти можуть їі застосовувати частіше, можуть виникати конфлікти між національним конституційним законодавством та правом Свропейського Союзу, і в той же час національні органи конституційного правосуддя намагаються розвивати свою діяльність більш дружньо до права ЄС та вести активний діалог шляхом звернення до Суду Європейського Союзу з метою тлумачення як Хартії, так і її судової практики, а іноді й змін. Нарешті, ще одна тенденція транснаціоналізації - це екстериторіальний ефект, який ми можемо побачити на прикладі GDPR - у сучасному світі, де цифрові технології, інтернет, зростаюча роль персональних даних отримують все більшу увагу, це вимагало розширення ефекту GDPR, у тому числі щодо контролерів та процесорів, які базуються поза межами СС.

Ключові слова: Хартія основоположних прав $Є C$, захист прав людини в $Є C$, тендениії захисту прав людини в СC, SOLVIT, Агентство СС з основних прав, GDPR.

Formulation of the Problem and Analysis of Publications. Human rights is an area of study which has become a classical one in legal science and researches in the field of constitutionalism. The EU is not an exception, and we see that there's been a great level of improvement in the protection of human rights, which relates to different areas, such as application of provisions contain in the EU Charter of Fundamental Rights by national authorities, development of new mechanism of human rights protection and even extraterritorial effect of some legal acts. The field has been examined by a number of scholars and practitioners, such as I. Dimitracopolus, G. de Búrca, Ingolf Pernice and others - definitely, different aspects have been taken into consideration. However, the focus of this article is to highlight modern trends of human rights protection in the EU.

Thus, the study objective of this article is to examine trends of human rights protection in the European Union as a feature of modern constitutionalism transnationalization.

Study Results. Currently, a number of mechanism have developed in the EU aimed on the protection of human rights. One of such mechanisms is the European Union Agency for Fundamental Rights, which was founded in 2007 [1]. As part of its activities, the Agency prepares large-scale surveys (such as discrimination against immigrants and ethnic minorities, violence against women, the rights of the LGBT community, etc.), comparative legal and social studies (such as access to justice, children's and justice rights, the rights of persons with disability and others), guides for practitioners (such as access to justice, asylum, cross-border migration and immigration, children's rights, protection of personal data and non-discrimination). In addition, the Agency cooperates with the European Parliament, the Council, the European Commission and the EU Agencies, national governments of the EU Member States, international organizations

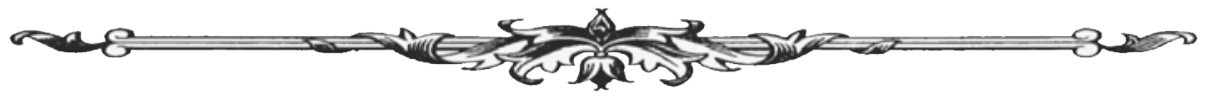


such as the Council of Europe, the UN, and the OSCE, as well as civil society organizations, academic institutions, and national organizations of human rights protection [2]. Thus, the activities of the Agency, financed by the EU budget, help to give particular attention to the problem areas regarding individual human rights.

Also, important role have the annual reports of the European Commission on the application of the EU Charter of the Fundamental Rights, giving both a general description of the application of the Charter and a separate practice of applying to each group of rights contained therein. For example, in the 2018 report, the Commission confirms that the accession of the EU as a party to the European Convention for the Protection of Human Rights and Fundamental Freedoms of 1950 remains a priority ${ }^{1}[3$, p. 27]. The report also states that the EU courts have substantially increased the reference to the Charter in their decisions. While there were 27 such references in 2010, their numbers increased to 195 in 2017 and 356 in 2018, and the most common rights they referred to were the right to an effective remedy and a fair trial, the right to good administration, equality before the law and the property rights [3, pp. 29-30].

The number of references to the Charter in national courts' applications to the Court of Justice of the European Union is also increasing - 84 in 2018, compared to 44 in 2017 and 19 in 2010 [3, p. 31]. Thus, we see an increase in the application of the Charter every year, which positively characterizes the Charter's role both in national justice and in the activities of bodies of the European Union.

An important element is that the Charter must be applied by national courts when considering the European Union law. The EU Human Rights Agency, already mentioned above, is preparing annual reports on the EU Charter of Fundamental Rights and its application by the EU Member States. In its 2018 report, in particular, the Agency notes that, as in previous years, the role and meaning of the Charter remain ambivalent - although national courts use the Charter, many references to it remain artificial. However, various court decisions show that the application of the Charter can add value and "make a difference" in individual cases [4, p. 43]. The report also contains a number of other interesting findings. The One is that when referring to the Charter, national courts refer to other sources, including the provisions of the European Convention for the Protection of Human Rights and Fundamental Freedoms, as well as national constitutional provisions. Also, the largest number of decisions (out of those analyzed by the Agency - 72 decisions from the 27 EU Member States cited by the Charter were related to legal rules related to transboundary movement, asylum and migration (22 decisions), and also with protection of personal data (10 decisions), judicial cooperation in criminal cases, non-discrimination (10 decisions) and judicial cooperation in civil cases (10 decisions). As for the specific articles referred to by the courts, this is Article 47 - right to an effective remedy and a fair trial (22 decisions), Article 7 - the right to privacy and family life (12 decisions), Article 52 - the scope of guaranteed rights (12 decisions), Article 51 - the scope of the Charter ( 8 decisions), Article 8 - protection of personal data ( 7 decisions), Article 4 - prohibition of torture (6 decisions) and others [4, pp. 45-47]

The application of the Charter is also analyzed in several contexts. The first is to determine the scope of application of the Charter and the fact that the question of whether the Charter should be applied and why is often left unresolved by national courts. The other cases include the use of the Charter as an appropriate legal standard in the application of national law, as well as the Charter in the context of the national legislative process whereby governments, members

The issue of EU accession to the European Convention for the Protection of Human Rights and Fundamental Freedoms of 1950 remains open. Yes, Part 2 of Art. 6 of the EU Treaty stipulates that the EU must accede to the European Convention for the Protection of Human Rights and Fundamental Freedoms, and such accession should not fall within the competence of the EU as defined in the EU Treaties and the functioning of the EU, as well (Article $6 \S 3$ ). EU Treaty) that fundamental rights as guaranteed by the European Convention for the Protection of Human Rights and Fundamental Freedoms and those which derive from the constitutional traditions common to the Member States of the EU are general principles of EU law. At the same time, the Court of Justice of the European Union in 2014 gave a negative conclusion on the draft Accession Treaty [404], and therefore the issue of EU accession is still in the process of being resolved. For more on EU accession to the European Convention for the Protection of Human Rights and Fundamental Freedoms, see. e.g., The Accession of the European Union to the European Convention on Human Rights, by Paul Gragl (Hart Publishing, 2013), 362 pages, Hardback, ISBN: 978184946460 [405]

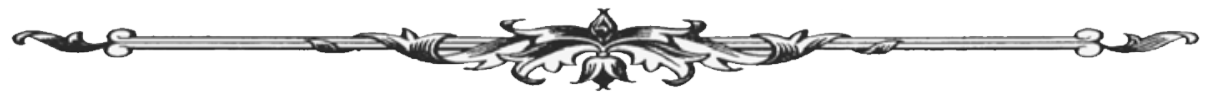


of parliament, parliamentary committees or independent institutions may refer to the Charter's provisions (for example, the French case where the legislation on protection of business confidentiality refers to Article 11 of the Charter (freedom of expression and information) and provides certain restrictions on the protection of personal data) [4, p. 45-54]. Finally, the Agency concludes by pointing out that there are currently insufficient national policies aimed at raising awareness and implementation of the Charter (while courts apply the Charter, other branches of government use it less frequently). Therefore, the Agency proposes, firstly, that the EU Member States introduce initiatives and policies aimed at raising awareness and implementation of the Charter, and secondly that the EU Member States should monitor cases of actual use of the Charter in national judicial decisions, and legislative and regulatory procedures to identify weaknesses and practical needs for better implementation of the provisions of the Charter at national level, in particular, to review provisions on the impact assessment of draft national legislation from Charter view [4, p. 54]. Therefore, while the Charter is being applied by the EU Member States, there is still room for further progress and more effective implementation of the Charter, both in national justice and in national parliamentary procedures.

It is important in the context of the application of EU law is the possibility of potential conflicts between EU law and national constitutional law. There are interesting views on this that are given by I. Dimitracopolus, Judge of the State Council of Greece [5]. He notes that there are two main types of conflicts between EU law and national constitutional norms, where the level of protection of EU law is higher than that afforded by national constitutional law, and where national constitutional law provides a higher level of protection than EU law [5, p. 1]. Judge Dimitracopolus also cites the legal basis for the relationship between EU law and national constitutional law, such as Art. 6 (3) of the EU Treaty, which states that the fundamental rights, as guaranteed by the European Convention for the Protection of Human Rights and Fundamental Freedoms since they derive from the constitutional traditions common to the Member States, constitute the general principles of EU law. This is also Art. 4 (2) of the EU Treaty, which stipulates that the EU must respect the national identities of the Member States, inherent in their fundamental structures, political and constitutional, including regional and local self-government, and must also respect state functions, as well as Art. 53 of the Charter, which provides that no provision of the Charter may be interpreted as restricting or adversely affecting human rights and fundamental freedoms, as they are recognized in their respective fields of application, EU law or international law to which they are a party, all Member States, including the European Convention for the Protection of Human Rights and Fundamental Freedoms and the constitutions of the Member States [5, p. 3-6]. As we can see, these provisions point to the role and importance of both international and national law, including the role of the national constitutions of the Member States. If to speak about ways how to resolve conflicts between EU law and the constitutions of the Member States, Judge Dimitracopoulos offers four basic options.

The first is the interpretation and application of constitutional norms in such way that they are the most friendly to EU law (as an example, the judge cites the decision of the State Council of Greece, which interpreted Article 14 (9) of the Greek constitution in accordance with the principle of proportionality, which is both a constitutional rule and a general principle of the EU and in accordance with EU Directive 93/37 / EU, as interpreted by the ECJ in Case C-213/07, Michaniki AE). $[5$, p. 6-7]. The second option is to interpret EU law in accordance with national constitutional law. As Judge Dimitracopolus points out, this interpretation is based on the fundamental constitutional principle that there are certain inalienable constitutional rights and fundamental values and principles established by the constitution that are outside European integration and thus limit the principle of the primacy of EU law. It is stated that such principle of interpretation was used by a number of courts, in particular the Constitutional Courts of Germany, Italy and Spain (an example of the German Constitutional Court interpreting the provisions on the European arrest warrant in accordance with the national constitutional guarantees on the rights of the accused $[5$, p. $7-8]$ These two ways of interpretation are relatively simple because, in our opinion, they are not so much about the conflicts between EU law and the constitutional law of the Member States,

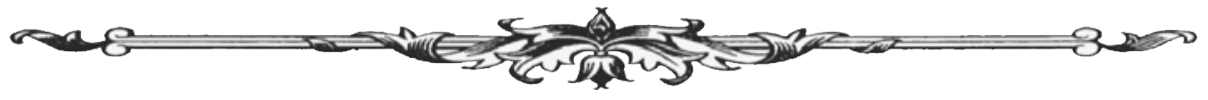


but rather their organic interaction to find the appropriate relationships and conduct the tests for compliance with the constitutional standards.

The two other ways that Judge Dimitracopolus cites are more complicated. The third way is to bring national court to the Court of Justice of the European Union to interpret or modify its practice so as to ensure the conformity of national constitutional law and EU law (and one of the successful ways is when the Italian Constitutional Court has successfully brought to the attention of the EU Court of Justice its previous practice concerning requirements not to apply the provisions of the Italian Criminal Code which limited the statute of limitations on certain offenses that may have involved infringement of the EU law about VAT. On the other hand, the Italian Constitutional Court noted that the statute of limitations provisions are essential in the Italian legal system, in particular in the context of the constitutional principles of the legality and non-retroactivity of criminal offenses and sanctions) [5, p. 8-9]. The latter is the non-application of EU law, which can only be done in exceptional cases as the last resort, with the basic doctrines being review on the basis of constitutional identity, national sovereignty, and the Ultra Vires doctrine, and review is based on the principle of legal certainty (up to which was the case, in particular the Czech Constitutional Court and the Supreme Court of Denmark) [5, p. 9-11].

So, as we can see, the question of the relation between national constitutional law and the law of the European Union remains open. Although in most cases the provisions of EU law and the constitutional law of an individual state will not conflict with each other, potential conflicts are still possible, especially in the context of cases where the application of EU law to certain factual circumstances traditionally governed by national law is quite controversial ( as it can be seen from the example where EU law required that the provisions of the Italian Criminal Code be applied). Another common case is the interpretation of certain principles, such as legal certainty. Instead, national courts try to "amicably" treat European Union law, which is facilitated by the possibility of applying to the European Court of Justice (which seeks to compromise and preserve the unity of the two-tier system of national law of a particular state and European Union law; if the problem concerns human rights, the guarantees provided for in the European Convention for the Protection of Human Rights and Fundamental Freedoms should also be taken into account. At the same time, the constituent acts of the EU, the Charter are designed to give maximum flexibility in interpretation, while emphasizing both the importance of the constitutional orders of the Member States (which have conferred powers on the EU, exercising their sovereign power) and the rules of the European Convention on the protection of human rights and fundamental freedoms, which is the basic modern human rights instrument in Europe. The principle of the primacy of EU law and potential conflicts with national constitutional law is also developed by P. Ravlusevicius [6]. In particular, he analyzes the aforementioned Ultra Vires doctrine, which is particularly widely used by the Constitutional Court of Germany. The Constitutional Court of Lithuania has similar approaches since Lithuania's participation in the EU is based on the constitutional requirements that must be respected, and therefore the constitutionality of such membership could be called into question if they were not observed during participation [6, p. 1379-1383].

Apart from using the Charter and European Union law by the courts of the Member States, the SOLVIT procedure should also be addressed. SOLVIT is a service provided by national administrations in each EU Member State, as well as Iceland, Liechtenstein, and Norway, which is mainly supported online. This service can be useful if a person believes that his/her rights as an EU citizen or business have been infringed by the public authority of another EU Member State and the person has not gone to court yet. SOLVIT is focused on resolving the case within 10 weeks, and the common issues that can be obtained through this service include recognition of professional qualifications, visa and residency rights, trade and service, vehicles and driving licenses, pension, work abroad, unemployment-related rights, health insurance, access to education, payments transfers across borders, VAT refunds. By submitting an application, the SOLVIT Center in a particular country will seek to find a solution with the appropriate public institution. The SOLVIT website also contains descriptions of cases that have been successfully resolved - such as the case of a Bulgarian national who worked in Greece and Bulgaria but was denied some of his pension

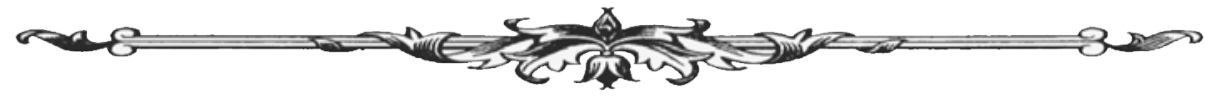


rights by the Greek authorities. SOLVIT helped to clarify the issues with the pension authorities of both countries and obtain a full pension for a Bulgarian citizen. Another example is a case where a French company appealed for a VAT refund to German authorities that had not responded within 10 months. After contacting SOLVIT, the situation was resolved within 6 weeks. Another example is the case where a truck driver, a resident of Belgium resident in Spain, after having exchanged his Belgian driver's license in Spanish, found that it had been banned from traveling for more than $50 \mathrm{~km}$ for a year. However, after SOLVIT intervention, the issue was resolved within 8 weeks and the restriction was removed from the driver's license [7]. As we can see, SOLVIT is a good example of how the EU is trying to put in place different procedures that can guarantee both citizens' involvement in resolving issues and successfully defend their rights. Thus, SOLVIT is a transnational European Union protection of rights mechanism.

While the provisions analyzed above relate to the protection of human rights within the European Union, a close correlation of the rules of national law of the EU Member States and EU law, there are also mechanisms of extra-territorial action of European Union law in the field of human rights. We can illustrate this with the example of very dynamic personal data protection legislation and the GDPR - General Data Protection Regulation, which came into force on May 25, 2018 [8]. GDPR imposes new, more stringent requirements for the protection of personal data and provides for significant penalties for violators - up to EUR 20000000 or 4\% of the total global turnover of the company, whichever is greater (p. 5, 6 p. 83) which has given considerable additional attention to the requirements of this Regulation. The territorial effect of GDPR is determined in Art. 3 and provides for three main cases - (1) processing of personal data by an EU-based controller or processor; (2) the processing of personal data of data subjects located in the EU, by a controller or processor not based in the EU, where their data-processing activities are linked to (a) the supply of goods or the provision of services to such entities EU data, whether or not they require payment from such data subjects; or (b) monitoring the behavior of data subjects, if such behavior occurs within the EU; and (3) processing of personal data by a controller not based in the EU but in a place where the law of a Member State is enforced by public international law. Thus, even if the controller or processor is not based in the EU but processes personal data of EU citizens (such as a Ukrainian entity), it is the subject to GDPR requirements. In this context, several questions arise, including what can be considered as the supply or provision of services to the EU law entities, or the monitoring of their behavior. Guidelines for GDPR Territorial Action [9] have been developed for interpretation by the European Data Protection Council and are proposed for public consultation, which addresses, including who may be considered data subjects covered by the supply of goods or services and monitored, as well as specific examples of how GDPR can be used. ${ }^{2}$

The issue of sanctions for breaches of GDPR requirements by non-EU controllers or processors is also debated. In general, this issue has not yet been properly addressed, as GDPR has only recently been put in place and the practice of its implementation is only being worked out. It is considered, for example, that sanctions may be imposed in the event of a breach, such as a refusal to open a foreign bank account, a ban on an EU law entity to continue streaming or transferring data to such a controller or processor, and the more general assumption that those controllers or processors that comply with GDPR will be more competitive in the market as they will be more trusted by the EU users and counterparties [10, p. 372]. Not taking into account the overall reputational risk associated with greater confidence in GDPR controllers and processors, the first 2 look quite real. Non-compliant controllers and processors may be the subject to sanctions if they are required to conduct certain activities within the jurisdiction of the European Union or have assets within the territory of the European Union. Another potential way to prosecute is in the case of a group of companies, some of which are based in the European Union and some outside. Also, there is an interesting case when Canada's public authorities assisted in investigating issues related to the GDPR breach by the Canadian company, which eventually forced it to comply with all

${ }^{2}$ Controller' means the natural or legal person, public authority, agency or other body which, alone or jointly with others, determines the purposes and means of the processing of personal data; 'processor' means a natural or legal person, public authority, agency or other body which processes personal data on behalf of the controller;

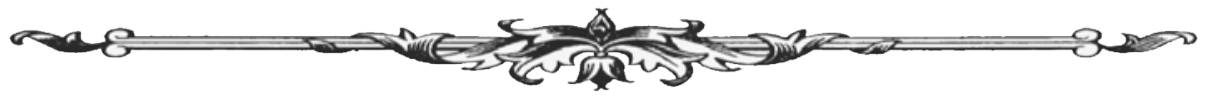


the requirements [11] - thus cooperating with States that are paying greater attention to personal data security can help within the extraterritorial GDPR. It is also theoretically possible to try to prosecute representatives of controllers or processors established outside the EU or to attempt to enforce the judicial or administrative decision in another country on a reciprocal basis, a ban on doing business in the EU, blocking websites or injuncting partners of such controllers or operators in the EU [12].

Conclusions. Thus, the protection of human rights within the European Union has a transnational effect and is also evidence of the transnationalization of modern constitutionalism. Within the EU, we see a close interconnection and interaction between national law of the Member States, the European Union law and the European Convention for the Protection of Human Rights and Fundamental Freedoms, in order to provide the greatest possible protection for the human rights. There has also been an increase in attention to these issues in the last decade, in particular, because of the entry into force of Charter of Fundamental Rights of the EU and the founding of the EU Agency for Human Rights. It is important that human rights and the Charter should be applied both by the EU institutions in the legislative process and applied in the work of national judicial authorities and parliaments in the legislative activity. The application of the Charter also faces certain challenges, in particular, national courts and parliaments could apply it more frequently, conflicts may arise between national constitutional law and European Union law, at the same time national constitutional justice bodies try to build their activities more amicable to the EU law and engage in an active dialogue through appeals to the European Union Court of Justice with the aim to interpret both the Charter and its case-law, and sometimes its amendments. Finally, another trend of transnationalization is the extraterritorial effect that we can see on the GDPR example - in the modern world, where digital technologies, the Internet, the increasing role of personal data are receiving increasing attention, which necessitated extending the effect of GDPR including controllers or processors based outside the EU. Thus, we see an extremely close interconnection of different states, bodies, rules of law and jurisdictions - modern human rights and their protection are truly transnational, as we may see it on the example of the European Union.

\section{References:}

1. COUNCIL REGULATION (EC) No 168/2007 of 15 February 2007 establishing a European Union Agency for Fundamental Rights. URL: https://fra.europa.eu/sites/default/files/fra uploads/351-reg_168-2007_en.pdf.

2. Introducing FRA. Web-site of the European Union Agency for Fundamental Rights. URL: https://fra.europa.eu/en/about-fra/introducing-fra.

3. 2018 report on the application of the EU Charter of Fundamental Rights, 05 June 2019. URL: https://ec.europa.eu/info/sites/info/files/2018_annual_report_charter_en_0.pdf.

4. Fundamental Rights Report 2019 - FRA Opinions. Chapter 2. EU Charter of Fundamental Rights and its use by Member States. URL: https://fra.europa.eu/en/publications-and-resources/ publications/annual-reports/fundamental-rights-2019.

5. Conflicts between EU law and National Constitutional Law in the Field of Fundamental Rights. By Ioannis Dimitrakopoulos, Judge of the Council of State of Greece. URL: http://www. ejtn.eu/PageFiles/17318/DIMITRAKOPOULOS\%20Conflicts\%20between\%20EU\%20law\%20 and\%20National\%20Constitutional\%20Law.pdf.

6. Ravluševičius, Pavelas (2011), "The Enforcement of the Primacy of the European Union Law: Legal Doctrine and Practice", Jurisprudence, Vol. 18, Issue 4, pp. 1369-1388. URL: https://www.mruni.eu/upload/iblock/472/6_Ravlusevicius.pdf.

7. SOLVIT. Solution to problems with your EU rights. URL: http://ec.europa.eu/solvit/ index en.htm.

8. Regulation (EU) 2016/679 of the European Parliament and of the Council of 27 April 2016 on the protection of natural persons with regard to the processing of personal data and on the free movement of such data, and repealing Directive 95/46/EC (General Data Protection Regulation) (Text with EEA relevance). URL: https://eur-lex.europa.eu/eli/reg/2016/679/oj.

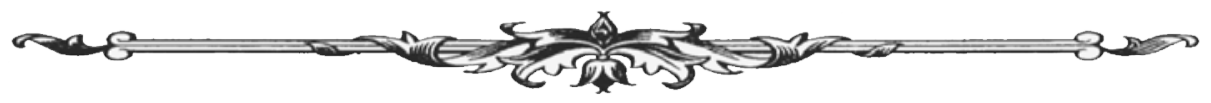


9. Guidelines 3/2018 on the territorial scope of the GDPR(Article 3) - Version for public consultation. URL: https://edpb.europa.eu/sites/edpb/files/files/file1/edpb_guidelines_3_2018_ territorial_scope_en.pdf.

10.М. Ковінько. Екстратериторіальна дія GDPR: ризики для українців та практичні рекомендації для уряду. «Молодий вчений» № 4 (68) квітень, 2019 р., с. 371-374. URL: http://molodyvcheny.in.ua/files/journal/2019/4/83.pdf.

11. Extraterritorial Application of The GDPR. URL: https://www.jdsupra.com/legalnews/ extraterritorial-application-of-the-gdpr-25522/.

12. Adèle Azzi, 'The Challenges Faced by the Extraterritorial Scope of the General Data Protection Regulation', 9 JIPITEC 126 (2018). URL: https://opencasebook.org/casebooks/104360-internet-platforms-gdpr-and-ip-enforcement-ceipi-advanced-training-2018/ resources/6.1.7-adele-azzi-the-challenges-faced-by-the-extraterritorial-scope-of-the-general-data-protection-regulation-9-jipitec-126-2018\#/.

КАНТОР Н. Ю., старший викладач кафедри правознавства, соціології та політології (Дрогобицького державного педагогічного університету імені Івана Франка)

УДК 342.9 (477)

DOI https://doi.org/10.32842/2078-3736-2019-6-1-5

\section{СУМІРНІСТЬ ЗАГАЛЬНИХ ЗАСАД СУДОЧИНСТВА І ПРИНЦИПІВ МЕДІАЦІЇ}

У статті досліджено проблему сумірності загальних засад судочинства та принципів медіації. Як суміжні правові інститути, судочинство та медіація характеризуються низкою спільних ознак, водночас є між ними і суттєві відмінності. Важливу роль у функціонуванні цих інститутів відіграє система принципів, як фундамент побудови будь-якого правового механізму розв'язання спорів. Підтверджено, що система основних засад судочинства відображена в Конституції України, Законі України «Про судоустрій і статус суддів» та галузевому процесуальному законодавстві. У принципах судочинства в найбільш концентрованому вигляді втілюються правова природа і завдання судової влади в Україні. Установлено, що нормативне закріплення системи принципів медіації відсутнє, як і нормативно-правова база медіації загалом. Доведено, що відсутність нормативного вираження принципів медіації не може бути перешкодою для функціонування цього інституту. Проаналізовано поширені в юридичній науці підходи до класифікації принципів медіації. Виокремлено загальноправові, галузеві/міжгалузеві та спеціальні принципи медіації. Загальноправові принципи виступають основою обох правових інститутів - і судочинства, і медіації - і забезпечують їх сумірність. Галузеві принципи характеризують присудову медіацію, наприклад, досудове врегулювання цивільних спорів за участю судді певною мірою підпорядковане принципам цивільного судочинства. До спеціальних принципів належать доступність, добровільність, рівність сторін, нейтральність медіатора, конфіденційність. Такі принципи виокремлені на основі узагальнення зарубіжного досвіду та аналізу рамкових міжнародних

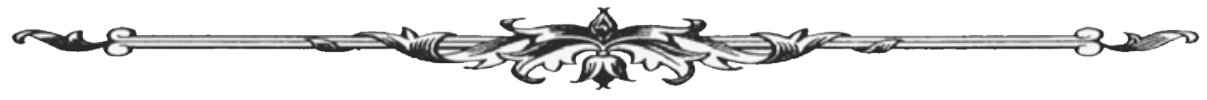

